\title{
SENSITIVITY TEST OF VIBRIO SP BACTERIA ISOLATED FROM DUMAI SEA WATERS TO ANTIBIOTICS (CIPROFLOXACIN, ERYTROMYCIN AND STREPTOMYCIN)
}

\author{
Febi Anisa Fitri*1, ${ }^{1}$ Feliatra $^{2}$, Dessy Yoswati $^{2}$ \\ ${ }^{1}$ Student of the Faculty of Fisheries and Marine Universitas Riau, Pekanbaru \\ ${ }^{2}$ Lecturer at the Faculty of Fisheries and Marine Universitas Riau, Pekanbaru \\ *febi.anisafitri@student.unri.ac.id
}

\begin{abstract}
The research was conducted from Feb until April 2019. The purpose of this study was to examine the resistance of Vibrio sp bacteria toward antibiotics (ciprofloxacin, streptomycin and erythromycin) isolated from Dumai sea waters. The spread of Vibrio sp bacteria has been found in sea waters, Vibrio sp bacteria have been found on the surface of faecal contaminated water and the existence of the population is related to organic waste disposal. Antibiotic susceptibility test was performed using Kirby-Bauer method. Resistance test showed that isolated V2, V9, V11, V13, V19, V23, V24 dan V28 were resistant to antibiotic ciprofloxacin, streptomycin and erythromycin with inhibitory zones ranging from 7,1 to 31,7 $\mathrm{mm}$. Isolated V2 and V9 are resistant to erythromycin, isolated V11, V13, V19, V23 and V28 are resistant to streptomycin and isolated V24 is resistant to ciprofloxacin.
\end{abstract}

Keywords: Vibrio sp, Pathogenic Bacteria, Resistance, Antibiotics

\section{PENDAHULUAN}

Pencemaran limbah dalam suatu perairan mempunyai hubungan dengan jenis dan jumlah mikroorganisme dalam perairan tersebut. Air buangan kota dan desa yang berpenduduk padat tidak hanya meningkatkan pertumbuhan bakteri koliform akan tetapi juga meningkatkan jumlah bakteri patogen seperti Salmonella, Shigella, Vibrio cholera dan Pseudomonas. Tingginya kandungan bakteri patogen akan mengkontaminasi biota-biota yang ada di perairan tersebut. Menurut Feliatra et al. (2012) kehadiran jenis bakteri patogen seperti Vibrio sp., Aeromonas sp., dan Pseudomonas sp dapat menyebabkan penyakit pada ikan budidaya sehingga perlu diantisipasi untuk pencegahannya.

Bakteri Vibrio sp adalah bakteri Gram negatif yang berbentuk batang bengkok, oksidase dan katalase positif, memfermentasikan glukosa tanpa menghasilkan gas dan mempunyai flagel polar. Bakteri ini sangat umum dijumpai di air payau dan laut. Sebagian bersifat saproba namun ada beberapa spesies yang menyebabkan penyakit Vibriosis pada hewan akuatik termasuk ikan. Penyebaran bakteri Vibrio sp di perairan laut telah banyak ditemukan karena bakteri Vibrio sp merupakan bakteri yang berasal dari laut (Mahbubillah, 2011), selain di ekosistem perairan, bakteri ini banyak ditemukan pada permukaan air yang terkontaminasi feses dan keberadaan jumlah penduduk berkaitan dengan pembuangan limbah organik, sehingga penyebaran bakteri Vibrio sp sangat mudah ditemukan.

Menurut Feliatra et al. (2012) kehadiran jenis bakteri patogen Vibrio sp, Aeromonas sp dan Pseudomonas sp akan menyebabkan penyakit pada biota laut yang 
perlu diantisipasi pencegahannya. Beberapa penelitian telah banyak dilakukan untuk mencegah bakteri patogen yang menginfeksi ikan yaitu dengan senyawa antimikroba. Senyawa antimikroba dapat diperoleh dari tanaman, hewan atau dihasilkan oleh mikroba yang umumnya dikenal dengan istilah biopreservatif.

Uji resistensi merupakan pengujian yang dilakukan untuk mengetahui kepekaan bakteri terhadap suatu antibiotik. Penggunaan antibiotik yang berlebih atau tidak terkendali menyebabkan efek samping yang berbahaya, yang menyebabkan bakteri-bakteri tertentu resisten (tahan) terhadap antibiotik. Uji resistensi yang akan di uji adalah bakteri Vibrio sp yang diisolasi dari perairan laut Dumai terhadap 3 antibiotik yaitu Ciprofloxacin, Erythromycin dan Streptomycin.

\section{METODE PENELITIAN Waktu dan Tempat}

Penelitian ini telah dilaksanakan pada bulan Februari - April 2019. Kegiatan isolasi bakteri Vibrio sp dan uji sensitivitas dilakukan di Laboratorium Mikrobiologi Laut Fakultas Perikanan dan Kelautan Universitas Riau.

\section{Metode Penelitian}

Penelitian ini menggunakan metode eksperimen untuk melakukan uji sensitivitas pada bakteri Vibrio sp yang diisolasi dari perairan laut Dumai dengan 3 antibiotik berbeda. Data primer diperoleh dari hasil pengamatan, pengukuran dan pengujian. Data sekunder diperoleh dari studi pustaka dan literatur-literatur serta diskusi dengan pembimbing. Data yang diperoleh dari hasil isolasi, identifikasi dan analisis disajikan dalam bentuk tabel dan gambar.

Pengujian sensitivitas bakteri patogen dilakukan dengan metode difusi agar, yang mengacu pada metode menurut Wolf dan Gibbons et al.(1996).

\section{Prosedur Penelitian}

Pengujian sensitivitas bakteri patogen dilakukan dengan metode difusi agar, yang mengacu pada metode menurut Wolf dan Gibbons et al. (1996). Bakteri patogen uji yang telah dimurnikan didalam media NB di ambil sebanyak $0,5 \mu \mathrm{L}$ dan ditanam kedalam media NA dan diratakan homogen. Setelah media yang berisi biakan bakteri patogen memadat diberi kertas cakram yang ditetesi dengan larutan antibiotik yakni Ciprofloxacin ®500mg, Erythromycin ®250mg dan Streptomycin ®100mg sebagai kontrol positif dan kertas cakram yang ditetesi media NB sebanyak $0,5 \mu \mathrm{L}$ sebagai kontrol negatif dan dilakukan pengulangan sebanyak 3 kali. Selanjutnya di inkubasi pada suhu $28^{\circ} \mathrm{C}$ selama 24 jam. Filtrat yang mengandung substansi antibakteri akan melakukan penghambatan terhadap bakteri patogen yang dibuktikan dengan adanya zona bening di sekitar cakram. Besarnya aktivitas antibakteri ditentukan dengan cara mengukur diameter zona bening di sekitar cakram.

Besarnya aktivitas dan zona hambat yang terbentuk dapat dipengaruhi oleh beberapa faktor yaitu jenis atau spesies bakteri, suhu dan waktu kontak antara bakteri dengan zat uji dan keberadaan bahan organik lain dalam zat uji tersebut (Fazier dan Westhoff dalam Yuhana, 2011) zona bening yang terbentuk disekitar kertas cakram merupakan zona aktivitas antimikroba terhadap bakteri patogen. Terbentuknya zona bening dikarenakan adanya penghambatan senyawa antimikroba terhadap sel-sel mikroba, secara umum mekanisme kerja dari suatu senyawa antimikroba dapat dilakukan dengan cara mengganggu atau merusak penyusun dinding sel, bereaksi dengan membran sel yang menyebabkan peningkatan permeabilitas seluler, inaktifasi enzim-enzim essensial dan 
destruksi atau inaktifasi fungsi dan materi genetik (Sari et al., 2013).

\section{HASIL DAN PEMBAHASAN Uji Sensitivitas}

Jenis bakteri Vibrio sp yang didapatkan berdasarkan hasil isolasi dan uji lanjut digunakan untuk uji sensitivitas terhadap antibiotik yang dilakukan dengan cara in-vitro.Hasil yang diperoleh pada uji sensitivitas bakteri Vibrio sp ke 32 isolat yang didapat terhadap 3 antibiotik berbeda yang dilakukan pengulangan sebanyak 3 kali dan untuk hasil rata-rata daya hambat paling resisten dapat dilihat pada (Tabel 1). Masing-masing antibiotik memiliki kemampuan yang berbeda-beda dalam menghambat pertumbuhan bakteri Vibrio sp, yang ditunjukkan adanya zona bening disekitar kertas cakram.

Tabel 1. Rata-Rata Daya Hambat Bakteri Vibrio Terhadap 3 Antibiotik

\begin{tabular}{cccc}
\hline \multirow{2}{*}{ Kode Isolat } & \multicolumn{3}{c}{ Diameter Zona Hambat $(\mathrm{mm})$} \\
\cline { 2 - 4 } & Ciprofloxacin & Erythromycin & Streptomycin \\
\cline { 2 - 4 } & $\mathrm{R} \pm \mathrm{SD}$ & $\mathrm{R} \pm \mathrm{SD}$ & $\mathrm{R} \pm \mathrm{SD}$ \\
\hline V2 & $21,6 \pm 5,8$ & $17,3 \pm 7,8$ & $12,3 \pm 3,3$ \\
V9 & $26,5 \pm 2,5$ & $10,2 \pm 4,5$ & $10,8 \pm 3,4$ \\
V11 & $22,9 \pm 5,2$ & $11,5 \pm 9,3$ & $7,9 \pm 4,3$ \\
V13 & $21,4 \pm 6,9$ & $17,9 \pm 5,2$ & $7,1 \pm 1,5$ \\
V19 & $20,8 \pm 0,6$ & $24,2 \pm 0,6$ & $11,0 \pm 3,4$ \\
V23 & $26,8 \pm 2,5$ & $31,7 \pm 8,1$ & $12,6 \pm 1,6$ \\
V24 & $16,0 \pm 2,2$ & $29,8 \pm 3,8$ & $22,5 \pm 1$ \\
V28 & $23,6 \pm 2,4$ & $27,2 \pm 13,5$ & $19,1 \pm 5,9$ \\
\hline
\end{tabular}

Keterangan : R : Rata-rata, SD : Standar Deviasi, Cakram 6 mm

Senyawa antimikroba yang menyerang bakteri akan merusak dinding selnya atau mencegah sintesisnya, Dinding sel yang rusak akan menimbulkan plamolisis. Jika protoplas ini diletakkan pada lingkungan dengan tekanan osmotik tertentu, mereka akan mengambil cairan dengan cepat, mengembang dan pecah. Jika fungsi integritas ini rusak maka makromolekul dan ion keluar dari sel kemudian terjadi sel lisis bahkan terjadi kematin. Membran sitoplasma dapat dengan mudah dikacaukan oleh agen antimikroba yang mengakibatkan terhambatnya pertumbuhan bakteri patogen (Jawetz et al., 2005 dalam Moritania et al. 2019).

Berdasarkan jumlah stasiun yaitu 5 stasiun didapat 8 isolat terpilih (Tabel 1) yaitu stasiun 1 terpilih isolat $\mathrm{V} 2$ dengan rata-rata antibiotik ciprofloxacin $21,6 \mathrm{~mm}$, erythromycin $17,3 \mathrm{~mm}$ dan streptomycin $12,3 \mathrm{~mm}$, stasiun 2 terpilih isolat $\mathrm{V} 9$ dengan rata-rata antibiotik ciprofloxacin $26,5 \mathrm{~mm}$, erythromycin $10,2 \mathrm{~mm}$ dan streptomycin $10,8 \mathrm{~mm}$ serta isolat V11 dengan rata-rata antibiotik ciprofloxacin $22,9 \mathrm{~mm}$, erythromycin $11,5 \mathrm{~mm}$ dan streptomycin $7,9 \mathrm{~mm}$, stasiun 3 terpilih isolat V13 dengan rata-rata antibiotik ciprofloxacin $21,4 \mathrm{~mm}$, erythromycin 17,9 $\mathrm{mm}$ dan streptomycin $7,1 \mathrm{~mm}$ serta isolat V19 dengan rata-rata antibiotik ciprofloxacin $20,8 \mathrm{~mm}$, erythromycin 24,2 $\mathrm{mm}$ dan streptomycin $11,0 \mathrm{~mm}$, stasiun 4 terpilih isolat V23 dengan rata-rata antibiotik ciprofloxacin $26,8 \mathrm{~mm}$, erythromycin $31,7 \mathrm{~mm}$ dan streptomycin $12,6 \mathrm{~mm}$ serta isolat V24 dengan rata-rata antibiotik ciprofloxacin 16,0 $\mathrm{mm}$, erythromycin $30,0 \mathrm{~mm}$ dan streptomycin $22,5 \mathrm{~mm}$ untuk stasiun 5 terpilih isolat V28 dengan rata-rata antibiotik ciprofloxacin 23,6 mm, erythromycin $27,2 \mathrm{~mm}$ dan streptomycin 19,1 mm. Hasil dari ke-32 isolat bakteri dari uji sensitivitas didapat 8 
isolat bakteri Vibrio yang termasuk resisten (Tabel 1) karena memiliki rata-rata yang terkecil dari isolat yang lainnya.

Menurut Melki et al., (2010) dalam penelitiannya terdapat perbedaan komposisi dan struktur dinding sel pada setiap bakteri. Bakteri gram negatif mengandung lipid, lemak atau substansi seperti lemak dalam presentasi lebih tinggi dari pada yang dikandung bakteri gram positif.

Pada bakteri Gram negatif struktur selnya lebih kompleks yang terdiri atas tiga lapis, yaitu lapisan luar berupa lipoprotein, lapisan tengah lipopolisakarida, dan lapisan dalam peptidoglikan (Syawal et al., 2017).

\section{KESIMPULAN DAN SARAN}

Berdasarkan hasil penelitian ini dapat diketahui bahwa hasil uji sensitivitas di peroleh 8 isolat dari 32 isolat yang diuji resistensinya yaitu stasiun 1 isolat $\mathrm{V} 2$, stasiun 2 isolat V9 dan V11, stasiun 3 isolat V13 dan V19, stasiun 4 isolat V23 dan V24 serta stasiun 5 isolat V28 yang tergolong dalam bakteri kategori kuat karena zona bening yang terbentuk paling kecil yang mengartikan bakteri tersebut masih tetap tumbuh pada area antibiotik yang diuji. Isolat V2 dan V9 resisten terhadap antibiotik Erythromycin, isolat V11, V13, V19, V23 dan V28 resisten terhadap antibiotik Streptomycin, isolat V24 resisten terhadap antibiotik Ciprofloxacin.

\section{DAFTAR PUSTAKA}

1. Feliatra., Y. Fitria, dan Nursyirwani. (2012). Antagonis Bakteri Probiotik yang Diisolasi dari Usus dan Lambung Ikan Kerapu Bebek (Cromileptes altivelis) terhadap Bakteri Patogen. Jurnal Perikanan dan Kelautan, volume 17(1), pages 16-25

2. Jatwetz, E., J.Melnick. (2005). Jakarta: EGC Jawetz, Melnick and Adelberg Mikrobiologi Kedokteran.

3. Mahbubillah, MA. (2011). Buku Budidaya Udang Vannamei

4. Melki., W. Ayu, Kurniati. (2010). Uji Antibakteri Ekstrak Gracilaria sp (Rumput Laut) terhadap Bakteri Escherichia coli dan Staphylococcus aureus. Universitas Sriwijaya, Indralaya-Indonesia

5. Moritania, R., I. Effendi, Feliatra. (2019). Isolation and Antagonism of Bacteria Test of Biota in the Mangrove Ecosystem Kayu Ara River Siak Regency. Asian Journal of Aquatic Sciences, volume 2(3), pages 21-27

6. Sari, Y.N.M., S. Sumyarti dan Jamsari. 2013. Isolasi, Karakterisasi dan Identifikasi DNA Bakteri Asam Laktat (BAL) yang Berpotensi Sebagai Antimikroba dari Fermentasi Markisa Kuning (Passiflora edulisvar flavicarfa). Jurnal Kimia Unand (ISSN No. 23033401), Vol 2(2).

7. Syawal, H., R. Karnila, A. Dirta, R. Kurniawan. (2017). Ekstrak Daun Rhizophora sp. Menghambat Pertumbuhan Bakteri Streptococcus agalactiae dan Edwardsiella tarda. Jurnal Veteriner, volume 18(4), pages 604-609

8. Wolf, C.E dan W.R Gibbons. (1996). Improved method for the determination of nisin. Journal Appl. Bacteriology, volume 80(4), pages 453-457.

9. Yuhana, N., A. Irianto dan H. Pramono. 2011. Rekayasa Mikroorganisme Inisiator Perifiton pada Kolam Budidaya Ikan Tilapia dengan Pemberian Konsorsia Mikroorganisme Unggul. Jurnal Perikanan (J. Fish Sci.), volume XIII(1), pages 13-21 